\title{
RESPONSIBILITY OF PRESIDENT AND CONGRESS FOR REGULATORY POLICY DEVELOPMENT
}

\author{
Hugh M. Hall, JR.*
}

There is nothing novel in the assertion that the process by which policies are formulated in the American system of government is a complex one. Yet acknowledgment of this fact of complexity is a necessary starting point in any meaningful attempt to describe and evaluate the relations of the President and Congress to the regulatory process, and the extent to which they provide effective guidance and control of the development of regulatory policies. ${ }^{1}$ The reasons for complexity are well-known: they derive not only from the magnitude and difficulty of many of the policies themselves, but also from the social and economic characteristics of America and from the political and governmental institutions through which policies are evolved. As a reminder of these latter conditions, one need only mention the diversity of interests that characterizes our society; the freedom afforded such interests to organize and express their wishes politically; the resulting play of competing forces upon and within our political parties and governmental institutions; and the built-in separation and competition within government itself, with dominationor even leadership-guaranteed to neither President nor Congress and with neither branch assured of unity of purpose or operations.

The implications of such complexity for the role of President and Congress are clear. In the first place, the assignment of responsibility for the actions of government, whether of a regulatory or nonregulatory nature, is difficult. To say that the President and Congress-either singly or jointly-are the agents for the development and ultimate control of policies is frequently only the beginning of analysis and description. A more realistic description would require, for example, at least an analysis of the political programs and movements of relevant interest groups for whom both the President and Congress are but agents or spokesmen. ${ }^{2}$

But accepting for symbolic and practical reasons the primary role of President and Congress in the policy-making process, we must emphasize that theirs is a shared and overlapping and, not infrequently, a conflicting responsibility. ${ }^{3}$ While by no means a novel point, this is a factor that is too frequently ignored by those con-

- B.A. 1942, Southern Methodist University; Ph.D. I953, University of Texas. Assistant Professor of Political Science, Duke University. Staff Member, Special Subcommittee on Legislative Oversight of the House Committee on Interstate and Foreign Commerce, U.S. House of Representatives, r959-60.

"As used in this article, the term "regulatory policies" refers mainly to those programs administered by the so-called independent regulatory commissions and by agents within executive departments who are required by law to follow procedures not dissimilar to those employed by the independent agencies. Outside the scope of this definition, unless otherwise indicated, are policies that are broadly regulatory in nature (such as fiscal policies) and are administered in more truly executive fashion by agents directly responsible to the President.

${ }^{2}$ See, e.g., an analysis of this type in David B. Truman, The Governmentai. Process passim (1958).

${ }^{3}$ Lawrence H. Chamberlain, The President, Congress and Legislation 448-64 (1946). 
demning both the substance of regulatory programs and the organizational forms employed to administer them. To stress the practice of shared responsibility, however, is not to insist upon an invariable pattern, nor to contend that such sharing is equally applicable to all types or levels of regulatory policy-making. There are instances in which Congress, for example, as compared with the President, bears almost sole responsibility for new regulatory schemes. ${ }^{4}$ In addition, a distinction must be made between the responsibility of the President in the initiation of policy for statutory enactment, where traditionally he has played a significant role, and his responsibility for subsequent development of administrative policies under the statutes, where for reasons to be mentioned later his role has been far less important.

In reaction to the fact of complexity and the diffusion of responsibility that accompanies it, there has developed the tendency of presidential "aggrandizement," to use the term of Professor Corwin, or the assumption by the President from time to time of a position of leadership vis-à-vis the Congress for the purpose of effecting new regulatory programs. 5 There is only a seeming contradiction between such presidential initiative and the pattern of shared responsibility between the two political branches. The presidential role is one only of leadership and not of domination or of a displacement of the Congress. Further, the role is not continuously played by the President or always effective when attempted. Regardless of the uneven application of such leadership, however, its growth over the course of the nation's history is among the more well-known aspects of executivelegislative relations. It is generally conceded to have resulted both from the greater political leadership potential of the unified presidential office and from a relative lack of such potential in the dispersed political and organizational form of the Congress. ${ }^{\circ}$

Another aspect of this same reaction to the dispersion of political authority and to the complexity within the policy process has been a realization of the need of some degree of coordination and control above the operating agency level of the administrative phase of policy development. Both President and Congress have been recognized as agents for achieving such goals. But once again, at least in the literature and recommendations of specialists concerned with administrative reorganization, the President has generally been considered more capable of effecting coordination and exercising those controls that are necessary for achieving political responsibility of administration in a democratic society. ${ }^{7}$ Accomplishments along this line, however, while not insignificant when viewed from the total perspective of the entire executive branch of government, have admittedly been quite limited with regard to regulatory administration, particularly in view of the prominent role

\footnotetext{
4Id. at 45 I.

${ }^{5}$ Edward S. Corwin, The President: Office and Powers 29-30 (r957). Sec also his article, The Presidency in Perspective, in Robert S. Rankin (Ed.), The Presidency in Transition 7 (x949).

- Wilfred E. Binkzey, The Man in the White House I42-6o (1958).

${ }^{7}$ E. Pendleton Herring, Public Administration and the Public Interest 347 (1936), and Presidential. Leadership 46-72 (1940). For a somewhat more qualified view, see Charles S. Hyneman, Bureaucracy in a Democracy 56-72 (1950).
} 
played by independent boards and commissions in the execution of regulatory programs. Yet the need of some type of overhead control and coordination is still recognized, even by those who are partisans of the independent agencies. ${ }^{8}$

A final relevant characteristic of the complexity in the political process is that the Congress, so organized as richly to express the diverse interests that compose it, continues to play a forceful role in the initial declaration of regulatory policies as well as in subsequent attempts to shape the content of programs developed by administrators under the statutes. In the latter aspect of its role, the Congress is assisted greatly by the "independent" character of the regulatory commissions that it considers, perhaps inconsistently, "arms of the Congress" and over which it jealously exercises "legislative oversight."

\section{I}

\section{Responsibility of the President}

In analyzing and evaluating the responsibility of the President for the development and control of regulatory policies, at least two sets of distinctions should be kept in mind: first, that between the role of the President as formulator (or advocate) of policies for enactment by the Congress, and that as developer of administrative policies under terms of basic regulatory legislation; and second, the distinction between the President and his staffs of personal assistants and advisers, and the "Presidency," meaning in effect the executive establishment theoretically under control of the chief executive. Obviously, both sets of distinctions are somewhat artificially drawn and should not be thought to represent more than broad categories to facilitate clarity of analysis. Moreover, further refinements properly could be drawn so as to distinguish different aspects of some of the roles here noted. For example, analysis of the role of the President as developer of administrative policies might well take into account, on the one hand, the President's relations with a single regulatory agency or program in which, by virtue of specific statutory provisions, he is permitted to intervene; ${ }^{9}$ and on the other, those relations with several agencies whose policies, in the President's view, require a degree of coordination. While such refinements have pertinence for later portions of this article, attention at this point will center upon the two sets of broad distinctions noted above.

\section{A. Formulator of Statutory Policies}

The history of regulatory policy development in the national government is replete with illustrations of the energetic and successful role played by the President in formulating and advocating policies for enactment by the Congress. ${ }^{10}$ It is mainly this function we have in mind when we speak of the President as "chief legislator." Such responsibility is derived not only from constitutional provisions, but also, and

\footnotetext{
s James M. Landis, The Administrative Process 24, 30 (1938).

${ }^{\circ}$ An example is his authority in foreign or overseas air route certification by the CAB. 72 Stat. 782 , 49 U.S.C. § $\mathrm{r} 46 \mathrm{~T}$ ( 1958 ).

${ }^{10}$ Chariberlan, op. cit. supra note 3 , passim.
} 
more importantly, from the position of political leadership that he occupies. In this latter capacity, he is spokesman for political interests and groups whose policy objectives, without presidential support, might otherwise be blocked by opponents in the Congress. This policy-forming role of the President, especially as it relates to a particular proposal, is apt to be transitory in nature, however, lasting only so long as political backing exists and the limited time and energy of the President permits. ${ }^{11}$ Its more dramatic and noticeable instances are associated with broad and significant innovations in the law, although regulatory statutes of narrow and less important character are known to have resulted from, or been influenced by, presidential recommendation. ${ }^{12}$

\section{B. Developer of Administrative Policies}

In the development of administrative policies, however, the President has not enjoyed such influence. Theoretically at least, the case should perhaps be otherwise, particularly in view of constitutional prescriptions that seem to invest him with the executive power of the government. ${ }^{13}$ And in reality, certain factors do enable the President to influence the administrative formulation of regulatory policies: his authority to appoint and, under certain conditions, to remove key officials; his power to designate the chairman of most of the independent commissions; his ability in some instances to review and approve administrative decisions; his control over administrative budgets; ${ }^{\mathbf{1 4}}$ and, to paraphrase the views earlier expressed by James M. Landis, "the over-shadowing stature of the President in matters of policy" that enables his view to prevail in a showdown with competing administrative agents. ${ }^{15}$

Despite these sources of strength, however, the President's role in administrative policy formation is severely limited. (Examples to the contrary are frequently drawn from periods of war and other disaster and, therefore, are not entirely appropriate indications of presidential potential in the absence of emergency.) ${ }^{\mathbf{1 0}}$ There are several immediate reasons for this limited role. Statutory provisions not infrequently place primary or sole authority in officials other than the President, although such officials are members of executive departments traditionally considered subject to

21 Truman, op. cit. supro note 2, at 398-404.

${ }^{13}$ For an estimate of the comparative influence of President and Congress on specific statutes enacted during this century, see ChamberLaIN, op. cit. supra note 3, at 450-52.

${ }^{13}$ U.S. Const. art. II. For an extensive treatment of the ambiguities that surround the meaning of the executive power in the Constitution, see Conwin, op. cit. supra note 5, at 69-169. Professor 'Truman refers to the "magnificent ambiguities" concerning the President's constitutional role as "chief executive." Truman, op. cit. supra note 2 , at $40 \mathrm{r}$.

14 These and other factors providing a basis for presidential influence of the independent regulatory agencies are discussed in Emmetre S. ReDFord, Administration of National Economic ControL 277.83 (1952). Professor Redford concludes: "Plainly, there is a conflict of trends on the independence of the regulatory commission. Presidential power bucks tradition. Facts run counter to the theory that the commissions are "wholly free from control by the President." "Id. at 283 .

${ }^{15}$ Note James M. Landis's comment to that effect in Administrative Process and Ethical Questions, Hearings Before the Special Subcommittee on Legislative Oversight of the House Committee on Interstate and Foreign Commerce, 85 th Cong., 2d Sess. 96 (1958).

${ }^{18}$ Sturm, Emergencies and the Presidency, in RANKIN, op. cit. supra note 5, at 121. 
presidential direction. ${ }^{17}$ An even more basic reason is Congress' practice of placing regulatory programs in organizations relatively free of the President's authoritythat is, in the independent regulatory commissions. ${ }^{18}$ Moreover, opportunity for intervention by the President into administrative policy formation is limited by procedural requirements designed to guarantee due process to persons subject to the law. An example of such requirements is the practice, either prescribed by statute or sanctioned by custom, of determining administrative policies by judicial-like, "onthe-record" proceedings. ${ }^{19}$ Such proceedings are used particularly, although by no means exclusively, by the independent regulatory commissions for policy development and are frequently severely criticized by many students as obstacles not only to planning and timely policy formulation by the commissions, but also to necessary policy direction and coordination by the President. ${ }^{20}$

\section{President and the "Presidency"}

But a more fundamental reason is found in the complexity of the American political environment, to which we have previously referred, and the resulting diffusion of power within the structure of the executive branch of government that the President nominally heads. Political scientists and students of public administration in recent times have taken an optimistic view of the potentialities of presidential control of administration and have advocated structural and other changes to secure an integrated, coordinated approach toward policy development. ${ }^{21}$ They rightly stress the institutional character of much presidential decision-making and the resulting need of certain administrative arrangements to facilitate the securing of timely, consistent, and responsible decisions. With such arrangements, they suggest, the gap between the President and the executive branch can be narrowed,

27 ". . . there is not too great a difference between the allegedly 'independent' agencies and those technically a part of some Executive Department. The President's arbitrary interference with the operations of the Commodity Exchange Administration would be subject to resentment equal to that engendered by a similar interference with the Securities and Exchange Commission. The same would hold whether it involved Food and Drug Administration or the Federal Trade Commission." JAMES M. Landis, Report on Regulatory Agencies to the President-Elect 30 (1960) [this report has been published as a committee print by the Subcommittee on Administrative Practice and Procedure of the Senate Committee on the Judiciary, 86th Cong., $2 \mathrm{~d}$ Sess. (I960); it is hereinafter cited as Landis REPORT].

${ }^{18}$ Marver H. Bernstein, Regulating Business By Independent Commission 127-63 (1955). Sec also REDFORD, op. cit. supra note 14 , at 275-76.

${ }^{10}$ The prevalence of a judicial-like approach to decision-making in the agencies, particularly as it affects the ability of the President to play a role in policy formulation, raises, as is noted more fully in latter portions of this article, the question of separation of functions in regulatory administration. If decisions are to be reached on the basis of facts set forth "on the record" by methods typical of courts, then', the question is asked, how can the President be permitted to influence the decision without destroying the judicial character of the process? One answer, of course, has been to separate completely the planning and rule-making duties of an agency from its judicial duties, thereby enabling the President to intervene in the performance of the first but not the latter duties. The obvious inference of this proposal is that such separation can be made without seriously crippling the administration of the law. But see infra notes 21-23.

${ }^{20}$ Bernstein, op. cit. supra note 18 , at $179-82$.

21 Prestdent's Comm. on Administrative Management, Administrative Management in the Government of the United States passim (I937). The Committee was composed of three wellknown political scientists and/or students of administration. 
if not closed, and the symbolic role of presidential leadership, authority, and responsibility for policy formation can be made a reality. Yet the complex and diffused character of political power, mentioned above, produces a major distinction between the President and the "Presidency," or between the President as a powerful but nonetheless politically limited occupant of the executive office and the executive establishment that he heads. Professor Corwin tells us that the entire history of the presidential office has been one of aggrandizement. ${ }^{22}$ Moreover, the last several decades record a continuing and on-the-whole successful effort to make the President a more effective chief executive. ${ }^{23}$ But the growth of power and effectiveness is a relative matter and must be measured not only against the weaker and less effective conditions of the past, but also against the obstacles of the present. A realistic appraisal of current conditions will show that a significant obstacle is the diffusion of power within the executive branch of government itself, the effect of which is to create an important gap between the President and the many executive departments and agencies that mere organizational and management improvements cannot fully close. ${ }^{24}$ The "Presidency"-so frequently used in an almost unthinking way as a substitute term for the President-is, in reality, a great mass of people and agencies that, in organizational form, has only a partial resemblance to the unity of the presidential office. As a consequence, men theoretically responsible to the President are free at times to recommend and develop policies either beyond the concern or knowledge of the chief executive or in direct contradiction of expressed presidential views. In this regard, the executive branch displays many of the separatist characteristics of the Congress, and for the same reasons. Of course, the point must not be carried too far; but at least it must be acknowledged. Otherwise we may expect too much of the President not only as formulator of policies for enactment by the Congress, but more importantly for our purposes here, as developer of administrative regulatory programs.

\section{II}

\section{Executive Integration and Independent Regulatory Agencies}

Much of the foregoing description of the President's role in administrative regulation can be illustrated through a brief review of proposals and efforts in the last twenty-five years to integrate the independent regulatory agencies into executive departments.

\section{A. Meaning and Goals of Executive Integration}

The idea of executive integration of administration has occupied an important place in both the literature and practice of American government throughout this

\footnotetext{
${ }^{22}$ Corwin, op. cit. supra note 5, at 29-30.

${ }^{22}$ A similar judgment is expressed by Fritz Morstein Marx elsewhere in this symposium. See Morstein Marx, Administrative Regulation in Comparative Perspective, infra at 307, 313-14.

${ }^{24}$ Long, Power and Administration, 9 Pub. Adman. Rev. 257 (1949).
} 
century. ${ }^{25}$ In fact, it is possible to speak of an "integrationist movement" operating on all levels of government: the establishment of strong-mayor and city-manager systems in municipal government; state government reorganizations resulting in increased authority of the governor over administrative operations; and the continuing efforts to alter the structure of national administration to bring about a more rationalized organization under control of the President. All of these movements are indicative of the prominence-and, to some extent, the persuasiveness -of the integrationist concept in recent decades.

The meaning of integration is suggested, perhaps somewhat formally, in terms of the following requirements. ${ }^{28}$ In the first place, authority for the direction of administration should be concentrated in the hands of the elective chief executive. Secondly, similar functions should be grouped in the same departments or agencies in order to promote consistency and reduce overlapping and waste in the application of the law. Third, each of the departments should be headed by a person appointed by, and responsible to, the chief executive, who delegates a portion of his authority to each department head. Fourth, to facilitate effective control of his subordinates and all administrative operations, the chief executive should have a relatively narrow "span of control"-that is, he should attempt to supervise the activities of as few subordinates as possible. Therefore, the number of department heads directly responsible to the chief executive should be kept to a minimum feasible with effective operations. As a fifth requirement, the chief executive should have at his disposal certain necessary facilitative powers and staff assistance in order that he might be the chief administrator in fact as well as in name; for example, powers and staff aids in the areas of budget, planning, and personnel. Sixth, the chief executive alone should be considered the responsible agent and spokesman of administration, and consequently he, rather than his subordinates within the integrated structure, should be held accountable to the legislature (and the people) for the conduct of administration. Implicit in this requirement is the assumption that the legitimate functions of both the executive, in directing the administration of the law, and the legislature, in seeing that the law is responsibly administered, will be best achieved if each approaches the other through its leadership on a relatively unified, nonpiecemeal basis. This in turn assumes (or posits as necessary or helpful), in addition to integration of the executive branch, the existence of a fairly high degree of legislative integration, with resulting strength in its leadership and relative weakness in its subunits of organization, such as committees and their chairmen. A final requirement of particular importance for our purposes here is that much of the substantive policy to be followed by departments and agencies should be determined by the chief executive, or, at least,

${ }^{25} \mathrm{~A}$ brief account of the history of American public administration, including the role of the chief executive, is presented in Leonard D. White, Introduction to the Study of Public Administration $13-60$ (1955).

"For a description of the "integrationist model," see John M. PFiffner \& Robert V. Presthus, Public Administration I97-213 (1960). 
formulated in his name. Two considerations support this requirement. First is the fact that administration, far from being concerned merely with the simple, and neutral, application of policies already clearly determined by the legislature, is itself intimately involved in the formulation of policies under the basic statutes. ${ }^{27}$ And second is the requirement previously mentioned, that in an integrated administration, authority is vested in the chief executive. Since this is the case, he should be empowered to determine the substance of administrative policies under authority of controlling legislation. One practical consequence of this requirement is to deny the legislature the privilege of placing final authority for administering the laws in the hands of officials subordinate to the chief executive or in organizations independent of his control. One possible exception to the requirement, however, and an important one as we shall explain more extensively below, concerns policies affecting individual rights determined by judicial-like processes.

Executive integration is desirable, according to its exponents, on several grounds. Increased economy and efficiency in administrative operations almost always figure prominently in the reasons offered for a more integrated structure of government. ${ }^{28}$ Such results, however, are frequently difficult to prove and often appear as little more than ways of attracting support of tax-wary electorates and legislators for reorganization proposals. The really basic reasons for integration are twofold: more effective responsibility on the part of administrators, and greater consistency and vigor in administrative policy development. ${ }^{29}$ The achievement of each of these goals, it is said, is dependent mainly upon the ability of political leaders of administration to reflect broad public interests and to muster political power sufficient to exact from administrators programs that are consonant with such interests. Integration of the executive branch under the broadly representative and politically powerful position of the elected chief executive is believed to satisfy these requirements. In the national government, for example, the President is considered the most representative agent of the American people. Consequently, he is supposedly capable of taking a broad, rather than a narrow or particularistic, view of governmental policies and of achieving the coordination of administration that is the requisite of consistent programs. Moreover, by virtue of his broad political support, he theoretically also possesses the power necessary to hold subordinates accountable to the policies that he formulates in the public interest. ${ }^{30}$

\footnotetext{
${ }^{37}$ Friedrich, Public Policy and the Nature of Administrative Responsibility, in C. J. Friedrich \& Enward S. Mason (Eds.), Public Policy 5 (r940).

${ }^{38}$ Not all government reorganizations are undertaken to provide greater integration of the structure and operations of administration; but practically all are justified in terms of economy and/or efficiency. Yet, during this century, reorganization efforts frequently have been guided, in part at least, by the "principles" of integration; when that was so, then integration was another means of achicving economy and/or efficiency. Note, for example, the heavy cmphasis placed upon these goals in the reports of the first Hoover Commission. See Comm'n on Organization of the Executive Branch of the GovernMENT, CONCLUDING REPORT passim (I949).

${ }^{29}$ President's Comas. on Admistrative Management, op. cit., supra note 21 , at 3, 29, 30, 36-37,

${ }^{80}$ Ibid.
} $4 I$. 


\section{B. Independent Commissions and the Failure of Integration}

We have previously acknowledged that the integrationist concept has not been without influence in the executive branch of the national government. Measured strictly by all of the requirements noted above, the results perhaps have not been great; at least one is still impressed with the "disintegrated" character of the national administration. Yet numerous studies and investigations conducted in recent decades have had that concept as their standard, ${ }^{\mathbf{3 1}}$ and certain changes in organizational structure and improvements in management techniques, particularly in the creation of more effective staff assistance for the President, are indicative of the impact of some of the so-called "principles" of integration. Greatest resistance to integrationist claims has come, perhaps, in the area of regulatory administration. Long and continued reliance upon the independent boards and commissions for major regulatory tasks is the most obvious indication of such resistance. In fact, in the late I930's, when the case for executive integration of the national administration received its most classic statement, ${ }^{\mathbf{3 2}}$ some opponents claimed that the integrationist movement centered "around questions concerning the organization, the relationship, the functions, and the control over the actions of independent regulatory boards and commissions."33 The effects of the movement upon the regulatory commissions at that time were virtually nil, however, and subsequent reorganization studies until recent months either by-passed the issue or found positive reasons for continuing the commissions. ${ }^{34}$ And although various factors in the relations between the President and the regulatory agencies have had the effect, over the years, of reducing the degree of agency independence of the chief executive, ${ }^{35}$ the commissions remain today as primary examples of a disintegrated national administration.

The fact that "independence" of the regulatory commissions has consisted primarily of freedom from presidential control (rather than from control by Congress or clientele groups) $)^{36}$ is perhaps enough to explain the concern that they create for proponents of executive integration. In their view, such freedom means the denial of those basic goals of integration that were mentioned above-namely,

${ }^{\text {s1 }}$ Concerning the impact of the integration concept, Professor Fesler has said: "[T] $]$ his ideal structure continues to command the respect of all official commissions and committees that have made major investigations of the administrative . . . needs of national, state, and municipal governments." Fesler, Administrative Literattre and the Second Hoover Commission Reports, 5I AM. PoL. ScI. REv. 135-36 (I957), quoted in Pfiffner \& Presthus, op. cit. supra note 26, at I98.

${ }^{33}$ Namely, President's Comm. on Administratrve Management, op. cit. supra note $2 \mathrm{x}$.

${ }^{33}$ Frederick F. Blachly \& Miriam E. Oatain, Federal Regulatory Action and Control i 43 (1940).

${ }^{34}$ Examples of generally favorable responses to the independent commissions by official reorganization study groups may be found in the reports of the first Hoover Commission and its task force on regulatory commissions. Comm'n on Organization of the Executive Branch of the Government, Regulatory Conmissions passim (1949), and TAsk Force Report on Regulatory Commissions passim (1949). If the so-called Hector Memorandum, infra note 38 , is considered a "reorganization study," it qualifies as a recent example of renewed attack upon the independent agencies. The LANDIs REPORT and the REDFORD REPORT, infra note 78 , do not so qualify, since neither seeks outright elimination of the commissions.

${ }^{36}$ See supra note I4.

${ }^{80}$ BERNSTEIN, op. cit. stupra note 18 , at I5I-52, $157-60$. 
effective administrative responsibility, and consistency and vigor in policy development. As the authors of an important study of administrative regulation explained the integrationist view in the r930's: ${ }^{37}$

... many of the most important problems of present-day economic life, such as the regulation under law of transportation, communications, water power, finance, fuel, trade and commerce, shipping, the tariff, securities and exchanges, labor relations, are given over to independent and separate highly specialized authorities in respect to the entire field of economic regulation.

\section{Moreover,}

... whereas the regulatory agencies are applying and developing broad economic and social policies, they are removed from any effective political control comparable to that exercised over other administrative agencies, which are also in some measure formulating policy. The independent boards and commissions are not tied together in respect to policy by the superior executive direction of the President of the United States, since he can exercise very little control over them except through the power of appointment. If the members of a commission are numerous, have staggered terms of office, possess a long tenure, and can be removed only for cause, his control is almost negligible.

Similar points have again been cited in quite recent attacks upon the regulatory commissions. ${ }^{88}$

The failure of the earlier attacks and the continued use of the commissions today invite explanation. The reasons, already suggested in our earlier discussion of presidential responsibility, illustrate rather well the obstacles to increased authority for the President in regulatory administration. The most basic and underlying reason relates to the political implications of executive integration. Administrative relationships, say, of President to independent commissions or to bureaus within executive departments, generally reflect existing power relations among participants in the political process, including, in addition to the President and administrative agencies themselves, Congress and relevant interest groups. In very practical terms, proposals for executive integration contemplate not only a rearranging of the somewhat technical administrative relationships within the executive branch of government, but more fundamentally, a restructuring of the power relations of these various participants. In other words, a re-ordering of administrative relationships is the occasion for-in fact, is dependent upon-a re-ordering of political power relationships. ${ }^{39}$ This truism of reorganization politics helps explain the failure of attempts to bring the independent regulatory agencies under control of the President. For that failure reflects the President's inability to build sufficient political power to overcome "the strength and vitality" of those relationships among

\footnotetext{
${ }^{37}$ BlACHLY \& OATMAN, op. cit. supra note 33, at $168-69$. It should be said that the quotations in the text above do not represent the views of the authors of the volume from which they are taken.

${ }^{2}$ Hector, Memorandum to the President: Problents of the CAB and the Independent Regulatory Commissions, 69 YALE L.J. 931 passim ( 1960 ) [this report has been published as a committec print by the Senate Committee on Government Organization, 86th Cong., 2d Sess. (1960)]. See also the Landis REPORT and the REDFORD REPORT, infra note 78.

${ }^{30}$ This idea is explained more fully in Truman, op. cit. supra note 2, at 432-33.
} 
independent agencies, their supporting interest groups, and the diffused elements of leadership in the Congress that profit from a maintenance of the status quo. ${ }^{40}$ Such inability, in turn, is traceable to the pluralistic and dispersed character of American politics and the consequent difficulty of generating that unity of political power, in either the Presidency or the Congress, that the theory of executive integration requires.

Other reasons for the failure of executive integration have to do with assumptions about the nature of regulation that supposedly distinguishes it from other types of governmental endeavor and about the most effective and fair organizational means for conducting the regulatory function. These assumptions are felt to justify the existence of the independent regulatory commissions and have been influential in the successful resistance to efforts to integrate the commissions into executive departments of government.

Advocates of executive integration have difficulty in finding truly distinctive characteristics in the substance of regulation that merit its administration by independent commissions rather than by executive departments. Such is not the case, of course, with partisans of regulation by commission. A somewhat lengthy quotation from a study in the I930's will show an attempt to state the relevant distinctions: $:^{41}$

There is a clear line of demarcation between the types of economic situations controlled by the Government departments and their subdivisions and those regulated by the independent boards and commissions.

Broadly speaking, and with some exceptions, the Government departments and their subdivisions are regulating and controlling business, through an exercise of what is virtually the police power, in the interests of public health, safety, and the prevention of fraud; whereas the independent boards and commissions are dealing with large economic problems such as monopoly, unfair methods of competition, price discrimination, reasonableness of rates and services, preventing speculation, stabilizing industry, regulating competing carriers in such a way as to guarantee adequate air, water, motor vehicle, pipe line, and railway transportation systems, and regulating the relationships between employers and employees. In the first type of regulation, the police formula of regulation is largely applicable; that is, a fixed rule of law, a charge that the law has been broken, and a decision. In the second type of regulation are involved questions of public policy, questions of economic relationship, and problems of public management. The regulatory process necessitates the development of more detailed lines of policy from rather general legislative declarations and also the application of these more detailed policies to specific cases.

Other observers describe the work of the regulatory commissions as concerned primarily with supervising the economic integrity and development of particular industries and with policing certain practices within business or industry as a whole. $^{42}$ In each instance, however, stress is placed upon the broad and discre-

${ }^{\circ}$ The quoted words are Professor Truman's. Id. at 433.

${ }^{11}$ The Brookings Institution, Investigation of Executive Agencies of the Government, S. REP. No. 1275, 75th Cong., Ist Sess. $769-70$ (1937).

${ }^{6}$ James M. Landis, The Administrative Process 23 (1938). 
tionary nature of regulatory responsibility, coinciding with particular lines of business, or with given industries, or, in some instances, with the entire economy.

For supporters of the regulatory commission, a consequence of such responsibility is the necessity of establishing organs of government whose legal and technical competence coincides with the realities of the industries or practices to be regulated and whose methods of procedure meet the standards of fairness traditionally required of democratic government. The independent commission, it is felt, best serves these needs. Why this is so was explained by the Hoover Commission task force on regulatory agencies in terms of commission expertness, group decisionmaking, continuity of policy, and impartiality. ${ }^{43}$ It found expertness in the commissions derived from "fixed terms of reasonable duration, and the tradition of reappointment," and from the aid rendered by older to newer members of the agency. Group decisions and policy-making, characteristic of boards and commissions and representing the "combined judgment" of several knowledgeable men, provide "a barrier to arbitrary or capricious action and a source of decisions based on different points of view and experience." Moreover, "group consultative action" reduces the "likelihood of sudden change in policy." Thus, continuity of policy, further assured by long, staggered terms of office and by limits on the removal of members, is another advantage of regulatory commissions, since it enables industrial managers "to plan ahead" and adapt their private operations to the requirements of public policy. And finally, the commission form of organization permits impartiality of regulation and freedom from political control. Again, this is possible by virtue of group leadership and security of tenure, which permit resistance to "outside influence." "Moreover, since the activities of the commission may be more subject to public scrutiny than would be a single bureau in a large department, there is greater opportunity for exposure of pressures or improper actions." Then too, "hearings and similar safeguards against arbitrary actions" may be more effective when combined with group decision-making.

One further justification (and explanation) of the independent commission relates to the necessity of unifying government's approach to the regulation of a particular industry or business practice. Perhaps James M. Landis, in his early and brilliant analysis of the regulatory process, explained best the character of this need and the manner in which the new "administrative" agencies were designed to satisfy it. According to Landis, ". . . the administrative [agency] differs not only with regard to the scope of its powers; it differs most radically in regard to the responsibility it possesses for their exercise. In the grant to it of that full ambit of authority necessary for it to plan, to promote, and to police, it presents an assemblage of rights normally exercisable by government as a whole."

\footnotetext{
${ }^{18}$ Comm's on Organization of the Executive Branch of the Government, Task Force Repont on Regulatory Commissions r9-25 (r949). The quotations in this paragraph of the text are taken from the pages cited here.

" James M. Landis, The Administrative Process 15 (1938).
} 
tion of powers and responsibility in the regulatory agency comports with, or indeed is caused by, a similar unity in regulated industries: $:^{45}$

As the governance of industry, bent upon the shaping of adequate policies and the development of means for their execution, vests powers to this end without regard to the creation of agencies theoretically independent of each other, so when government concerns itself with the stability of an industry it is only intelligent realism for it to follow the industrial rather than the political analogue. It vests the necessary powers with the administrative authority it creates, not too greatly concerned with the traditional tripartite theory of governmental organization. The dominant theme in the administrative structure is thus determined not primarily by political conceptualism but rather by concern for an industry whose economic health has become a responsibility of government.

Similar disregard of the "triadic contours" of organization and function derived from the theory of separation of powers is evident also in those commissions responsible for policing business practices rather than whole industries. ${ }^{46}$ And although the combination of various powers, methods, and instruments in a single commission is regarded by some as a source of administrative unfairness, ${ }^{47}$ or a barrier to adequate policy planning, ${ }^{48}$ or an impediment to government-wide coordination of policies, ${ }^{49}$ such a unified approach is strongly defended, as indicated above, as necessary to the balanced and effective development of regulatory programs.

These various claims and assumptions regarding the nature of administrative regulation and the qualities of regulatory commissions are said to justify independence from presidential control. No attempt will be made at this point to evaluate these assumptions-that is, to question the alleged distinction between executive-type and commission regulatory programs, either as to the substance of such programs or methods and procedures employed, or between the relative capacities of departments and commissions for fairness and expertness in administration of the law. ${ }^{50}$ We need only acknowledge that regardless of the soundness of such distinctions, these arguments in favor of independent commissions have appeared sufficiently persuasive to account, in part at least, for the failure of the integrationist movement in the national government.

More specifically, this failure is traceable to the inability of proponents of integration to offer alternative suggestions that appear capable of providing the benefits allegedly arising from the commission form of organization, while at the same time achieving the basic goals of executive integration. Or to state the matter differently, the failure is revealed in the inability of integration proposals to provide acceptable

${ }^{45} I d$. at II-I2.

${ }^{4} \mathrm{Id}$. at $\mathrm{I} 6$.

"Robert E. Cushuan, The Independent Regulatory Commissions 700-01, 708 (1941). The American Bar Association's continuing plans to "remedy" this situation are mentioned elsewhere in this symposium. Benjamin, A Lawyer's View of Administrative Procedure-The American Bar Association Program, supra at 203.

${ }^{48}$ Hector, supra note 38 , at 932.

${ }^{60}$ Cushman, op. cit. supra note 47 , at 688 .

${ }^{50}$ Redford's evaluation of the Hoover Commission task force's views on the independent agencies is pertinent here. Emmetre S. Redford, Administration of National Economic Control 286-87 (1952). 
answers to such basic questions as these: Which aspects of commission duties or functions should come within the authority and responsibility of the President? How is executive integration of regulatory administration to take place without, at the same time, sacrificing (or appearing to sacrifice) those values of fairness and impartiality of administration that the independent commissions supposedly assure? How can the regulatory responsibilities of the President be increased and fairness and impartiality of decision-making assured without, at the same time, so disunifying the regulatory process as to render it less effective than it presently is? Essentially, two related problems are involved in these questions: first, that of providing government-wide direction and coordination of regulatory policies under the President; second, that of assuring impartiality and objectivity of the judicial functions in the context of such an integrated administration. And underlying both problems is the issue of unified versus disunified administration of regulatory programs on both the agency and government-wide levels. ${ }^{.1}$

Proponents of executive integration have sought answers to these questions-or solutions to the underlying problems-largely in terms of separation of functions. ${ }^{62}$ Viewing the independent commissions as serious obstacles to responsible policy formation and coordination, they have proposed that the President (or departments under his control) be given authority over those aspects of commission programs that involve the determination of policy, in addition to such traditional executive-type duties as investigations and law prosecution. ${ }^{53}$ But also acknowledging the need and desirability of fairness in the judicial-like functions of the regulatory process, they have advocated the creation of special, isolated bureaus within executive departments $^{54}$ or the establishment of administrative courts ${ }^{65}$ to carry out the judicial duties now performed by commissions. In both instances, the rationale is that of the separability of commission functions, and the recommended result, in addition to doing away with the independent commissions, is the division of the currently unified approach to regulation among two or more organs of government.

Such a result has not been acceptable, to date, to the Congress, the regulated industries, or, of course, the commissions themselves. While the reasons for rejecting these proposals are mixed, two factors about commission operations appear to have had significant influence. One relates to the question of impartiality and fairness; the other, to the unity of functions on the operating agency level, as mentioned above. In the first instance, it is said that the internal separation of functions within the agencies themselves, particularly as required by the Administrative Procedure Act, largely solves the problem of unfairness that arises from the combination of prosecuting and judging functions in the same hands. ${ }^{58}$ And in the second instance,

"Id. at $3 \mathrm{I}_{4}-\mathrm{I} 5$, where reference is made to "a problem of unity at two levels."

o2 President's Comm. on Addinistrative Management, op. cit. supra note 21 , at 37-38. See also Cushman, op. cit. supra note 47 , at 708; Hector, supra note 38 , at 960,962 .

${ }^{58}$ Hector, supra note 38 , at $960-6 \mathrm{x}$.

54 President's Comm. on Administrative Management, op. cit. supra note 21 , at 37 .

${ }^{65}$ Hector, supra note 38 , at 962 .

The relevant provision of the Administrative Procedure Act is $\$ 5$ (c). 6o Stat. 239 (1946), 5 U.S.C. 
a strong case is offered to confirm the difficulty of separating the functions now in the regulatory commissions and distributing them among different organs of government. Moreover, the wisdom of such a separation is questioned in view of the intimate relationship among the various administrative methods employed in the over-all effort of an agency to accomplish its regulatory job. ${ }^{\mathbf{5 7}}$ For example, proposals to distribute the policy-making and planning functions of the Civil Aeronautics Board to an executive department and its adjudicatory function to a "true administrative court" $\overline{8}$ are attacked as providing too facile an answer to the interrelated problems of effectiveness and fairness of $\mathrm{CAB}$ route-certification proceedings. ${ }^{\text {59 }}$ For a decision as to which cities are to obtain new flight service, it is said, may well depend upon which carriers are willing to provide it. The intimate relationship between these two aspects of a single problem, therefore, makes difficult the classification of one as "policy-making" and of the other as "policyapplication," and argues for the performance of both by the same administrative agency. For this and related reasons, the necessity of a unified approach to single regulatory programs has been successfully presented and has seemed of greater importance than the unification or integration of all such programs under authority of the President.

\section{III}

\section{Responsibility of Congress}

Congress exercises its responsibility for the development and control of regulatory policies in two basic ways: first, by legislation, which creates the substance of policies and the organizational and procedural forms through which such policies are administered, and provides the money necessary to their support; and second, by

$\$ 1004$ (1958). Kenneth C. Davis's conclusion regarding the purpose and effect of this provision is as follows: "The main idea of the APA-internal separation-has proved itself generally sound and workable. Deficiencies of the APA provisions relate mostly to the refinements, especially the inapplicability of the provisions to some functions that call for separation of functions." 2 KenNetr C. DAvis, ADMiN1stratrve LAw Treatise $\$$ I3.II (1958). For the majority views of the Attorney General's Committee on Administrative Procedure, which helped to shape the provisions of $\S 5$, see Attorney General's Comm. on Administrative Procedure, Administrative Procedture in Government Agencies, S. Doc. No. 8, 77th Cong., Ist Sess. 55 (194I).

${ }^{87}$ A fairly typical, if perhaps somewhat prejudiced, expression of this viewpoint is found in the following statement of the General Counsel of the CAB in reaction to the Hector Memorandum: "Just as in theory the Board's functions are not and were not intended to be clearly segregated as policymaking and adjudication or legislative and judicial but an amalgamation of both, so in actual fact and practical application they are inseparable. The broad policy objectives and guidelines of the Act permeate virtually every action and decision by the Board. In authorizing new routes or fixing mail rates, for example, the Board is, of course, adjudicating in the sense that it is affecting private rights, but it is doing so only as a part of a broader Congressional purpose and always with the general policy objectives of the Act in mind. Adjudication is thus not an end in itself but a tool for proper effectuation of the public interest." Detciled Analysis and Evaluation of the Hector Memorandum to the President 17 (1960) [this may be found in Independent Regulatory Agencies Legislation, Hearings Before the House Committee on Interstate and Foreign Commerce, 86th Cong., 2d Sess. 465 (1960)].

${ }^{58}$ Hector, supra note 38 , at $960-63$.

"Auerbach, Some Thoughts on the Hector Memorandum, 1960 Wis. L. REv. 186 (1960). 
surveillance of the administration of regulatory programs. ${ }^{60}$ In addition, the Senate may influence the formulation of policies through its power to confirm or reject presidential nominees to administrative positions. Ordinarily, the performance of each of these functions is greatly influenced by the diversity of interests represented by the membership of the Congress, the disintegrated character of its organization and leadership, and the rules and traditions of its procedure, which, to a great extent, naturally reflect the diversity and looseness of organization in the two houses. ${ }^{01}$ Although the increased size and complexity of regulatory programs have caused an immense expansion of policy development by the President and administrative agencies, Congress shows no disposition to relinquish its own basic controls. In fact, the record of recent years indicates an increased involvement of Congress in the details of regulatory administration. ${ }^{62}$

\section{A. Regulatory Legislation}

It is the responsibility of Congress to declare by legislation the basic policy of a regulatory program. No issue arises regarding its right to perform this function. Rather, questions are directed to the effectiveness of its performance. Such questions as these reveal the really fundamental problems involved: Is the policy embodied in the statute relatively clear? Are its goals specified? Are there clear and consistent standards for guidance of the administrators? Has Congress resolved certain basic issues inherent in the regulation intended, or has it passed an impossible task on to the regulatory agency? Is the policy realistically conceived and adequate to meet the problems involved? Are administrators equipped with sanctions sufficient to the tasks before them? Are statutory policies kept relatively up to date in response to changing conditions and needs? Not all of these questions can be answered on the basis of "objective facts." Here, again, personal values and biases of the observer will, of course, affect the answers. As a result, generally mixed responses are given, for it is possible to pick illustrations that both confirm and deny any general allegation that is made. On the whole, however-and that may be just a convenient way of escape-it must be conceded that Congress too frequently has been deficient in the performance of these aspects of its policy-forming job. Examples may be found in the Communications Act, ${ }^{63}$ where language designed to regulate individual radio licensees provides only an indirect basis for control of networks and reflects no real recognition of the newer television medium; or in the Natural Gas Act, ${ }^{64}$ where the intention of Congress regarding Federal Power

\footnotetext{
${ }^{\circ 0}$ Hyneman presents a realistic appraisal of the role of Congress. Hrnessan, op. cit. supra note 7 , at 77-202. See also Heady \& Linenthal, Congress and Administrative Regulation, supra at 238, 253-60.

${ }^{91}$ Truman, op. cit. supra note 2, at 321-94. But see Ernest S. Griffith, Congress, ITs ConTEMPORARY Role vii (196r).

${ }^{62}$ Schwartz, Legislative Control of Administrative Rules and Regulations: The American Experience, 30 N.Y.U.L. Rev. 103I (1955); Cotter \& Smith, Administrative Acconntability to Congress: The Concurrent Resolution, 9 W. PoL. Q. 955 (1956).

${ }^{\text {os }} 48$ Stat. 1064,1083 (1934), 47 U.S.C. $\$ 307$ (1958).

${ }^{84} 52$ Stat. 821, 823 (1938), 15 U.S.C. $\$ 717,7^{1} 7 \mathrm{~d}$ (1958). See discussion of this problem in Cornelius P. Cotter, Government and Private Enterprise 23I-45 (1960).
} 
Commission jurisdiction over producer sales to interstate pipelines is, at best, cloudy; or in the Transportation Act of 1920, where the standard governing railway ratemaking by the Interstate Commerce Commission ("annual . . . fair return upon the aggregate value") was clearly inadequate to the task assigned. ${ }^{65}$

Yet 2 mild defense of the Congress must be offered, or at least a brief reminder given of factors that, to some extent, explain these deficiencies in regulatory statutes. In the first place, confusion or lack of clarity in regulatory goals and standards may be but a reflection of the magnitude and complexity of the problem to be solved or the industry to be regulated. The diffculty of reconciling the desire for "quality" television programs with the right of free speech, or of deciding the relative weight to be given to various criteria in assigning television channels, are illustrations. ${ }^{6 B}$ Or confusion in statutes may result from uncertainty about methods to achieve ambiguous but nonetheless desired goals. Trade regulation to maintain a "free competitive enterprise system" is an appropriate example. ${ }^{67}$

Secondly, at times, complaints about lack of clarity in statutes are but indications of disagreement with regulatory goals and represent attempts to avoid forceful regulation. Or, as a variation of this point, complaints not infrequently reflect dissatisfaction with what is considered weakness in regulatory legislation. No small part of the criticism of regulation by independent commissions, it seems, is traceable to this factor. ${ }^{88}$ There obviously are differences among men on the fundamental questions of what should be regulated and what should not, and concerning how forceful regulation, once initiated, should be. But it is well to remember that Americans, while not at all reluctant to use governmental power to achieve desired results, have generally eschewed the "comprehensive" approach toward regulation and have been content to proceed cautiously and on a piecemeal basis. There has been a willingness, to use the term of Professor Lindblom, to "muddle through." ${ }^{189}$ Such an approach may not satisfy some of us, but it is essentially the one expected of Congress as it formulates regulatory policies. And Congress should not be condemned on grounds of lack of clarity in statutory policies when those policies are relatively clear, but not forceful enough to satisfy a given observer.

A fourth factor concerns the relationship between clarity of regulatory purpose and specificity of statutory provisions, between the need of sufficiently detailed directions by the Congress and the probably more compelling need of breadth and generality in statutory policy statements. ${ }^{70}$ These relationships pose something

${ }^{\circ} 4 \mathrm{I}$ Stat. 456,488 (1926). Cited and discussed in EMmetTE S. RedFord, Administration of NATHonal Economic Control 69-70 (1952).

${ }^{\circ 6}$ The free speech issue arises not only because of the constitutional guarantee, but also, and more immediately, because of $\$ 326$ of the Communications Act, which forbids the FCC to interfere with that freedom. 48 Stat. I09I (I934), 47 U.S.C. $\$ 326$ (1958).

${ }^{07}$ Reference here, of course, is to such a statutory expression of "competitive enterprise" policy as $\$ 5$ of the Federal Trade Commission Act. 38 Stat. 7 17, 7 I9 (1914), I5 U.S.C. $\$ 45$ (I958).

${ }^{08}$ Jaffe, The Independent Agency-A New Scapegoat, 65 Y YLE L.J. Io68 (1956).

"Lindblom, The Science of "Mutddling Through" I9 PuB. AdMin. REv. 79 (1959).

${ }^{70}$ Redford provides a good discussion of these and related factors as they affect administrative program development. Exsmetre S. Redford, Administraton of National Economic Control 57-64 (1952). 
of a dilemma for the Congress, as well as for the administrator. On the one hand, it is obvious that clarity in regulatory goals flows from specificity and detail in legislation. But on the other, too much detail can cripple imaginative and flexible administration of the law, especially in response to changing conditions. How then, for example, does the language of section five of the Federal Trade Commission Act, with its prohibition of "unfair methods of competition," measure up under each of these contending needs? ? $^{71}$ Such ambiguity in the definition of proscribed business practices may well be the price that must be paid for a sufficiently flexible adjustment of the law by administration to certain emerging business methods. Regardless of the conclusion in this or any other example, however, the point to be remembered is that congressmen and legislative draftsmen are not always oblivious of such considerations, and ordinarily attempt to reconcile in a reasonable manner these conflicting requirements.

Finally, the effect of the composition, organization, and leadership of Congress upon its policy-forming role should be recalled. The diverse and disintegrated character of the legislature is the source of much confusion and ineffectiveness in regulatory statutes. Diversity and independence of membership and organization place a premium upon compromise, and compromise can at times produce inconsistent, confused standards or goals in legislation. Interested outside parties, permitted "access" and "influence" by the organization and methods of Congress, are not averse to introducing confusion into regulatory laws. ${ }^{72}$ Much or all of this is to be deplored, perhaps. But in evaluating Congress' responsibility in policy development, there is no harm in remembering what students in introductory courses in American government are rightly told-that the inconsistencies and confusions emanating from the national legislature are in no small way the result of the inconsistencies and confusions in the country at large.

\section{B. Surveillance of Administration}

It is also the responsibility of Congress to review the administration of laws it enacts. In performing this task, it inevitably attempts to influence or shape the content of regulatory policies. This is both a legitimate and necessary function of Congress, but one that is difficult of adequate performance and is easily abused. The methods and occasions of congressional review of regulatory policies are many and varied and well-known to all. Through its committees on appropriations, legislative and special investigating committees, as well as through individual congressmen, particularly, committee chairmen, and key staff personnel, Congress possesses innumerable agents of "legislative oversight" of regulatory policies. The quality and effectiveness of such oversight are uneven, however; and the resulting influence of Congress upon regulatory policies is, therefore, varied. In some instances, its influence produces administrative adherence to policies originally intended by Congress or assists in the legitimate and flexible adjustment of existing law to new

${ }_{71} 38$ Stat. 719 (1914), 55 U.S.C. \$ 45 (1958).

${ }^{72}$ TruMAN, op. cit. supra note 2, at 352-6r. But see GRIFFITH, op. cit. supra note 6r, at 151 . 
and unanticipated conditions. ${ }^{73}$ On other occasions, however, its influence results in an enlarging or narrowing of statutory policies to accord with views of individual interests, congressmen, or committees. ${ }^{74}$

The character of Congress' influence, of course, is immediately determined by the interest, judgment, and wisdom of its reviewing agents, and by the resulting quality and intensity of the review..$^{75}$ Accordingly, the results are mixed. ${ }^{76}$ For as would be expected among dozens of members and several committees directly concerned with regulatory policies, there is great variation in those factors that determine the quality of legislative oversight. In many cases, the approach to administration is guided by intelligence, understanding, and reserve. The competent members who are found on each committee, as well as experienced and resourceful staff personnel who assist them, provide vigorous, but balanced, surveillance of the development of particular regulatory programs. In a political system where power is divided and at times widely dispersed, responsible and effective government is achieved through the efforts of such men.

But not all conditions in Congress are so favorable for effective review. The very intensity and frequency of congressional oversight, which can be a basis of legitimate control of administration, may also disrupt and demoralize administrative efforts. Carried to an extreme, as it sometimes is, it can substitute congressional direction for the leadership and responsibility of agency officials. ${ }^{77}$ Then too, the approach of congressional review is too frequently narrow and particularistic, concentrating upon a single problem or limited range of problems at a given time. Such an approach may be conducive to thoroughness of review, but it also makes difficult the achievement of broad understanding necessary to more balanced programs of government. Related to this condition is the practice of according to semi-independent units (committees, chairmen) authority to speak for the whole of Congress on policy matters. This practice, again, is productive of expertness on administrative programs and, on the whole, is an indispensable attribute of the national legislature. But it can also be the basis for usurping administrative authority in decision-making and for twisting statutory policies to accord with the particular interest of a powerful member or committee of Congress. And finally, there is weakness in legislative oversight in the noticeable failure of Congress to maintain sustained or reasonably continuous review of administrative policy development. Such failure, of course, is related in part to inadequacy

\footnotetext{
${ }^{78}$ Note the comments to this effect in the "panel discussion" type of hearings on the regulatory process held by the Subcommittee on Legislative Oversight in 1958 . The panel was composed of administrative practitioners, agency members, and legal scholars, all of whom were conicerned with the regulatory process. Hearings, supra note I5, at 102-05.

"t James M. Landis cites, as an example, the role of the House Committee on Interstate and Foreign Commerce in "setting aside" the FCC's program for subscription television. Id. at 98.

${ }^{75}$ Attention should be called to the efforts made by Congress in 1946 to reorganize itself and improve its methods of operation, including its methods of surveillance of administration. See, in this regard, George B. Gallowhy, Congress at the Crossronds 230 (1946).

${ }^{70}$ See note 73 supra.

${ }^{77}$ See note 74 supra.
} 
of time and personnel to undertake the difficult and ofttimes tedious jobs of review. But to some degree, it is also caused by the discontinuity in the sessions of Congress, changes in congressional composition and leadership, and the narrow political environment in which review is frequently undertaken.

\section{Summary and Conclusion}

President and Congress share responsibility for the regulatory process. Neither can claim exclusive interest or authority in the statutory formulation or subsequent administration of regulatory programs. The actual role of each and their relationship in the regulatory process is determined not in any permanently fixed or precise manner, but rather from time to time and from policy to policy by the movement of political forces and the realities of institutional characteristics that shape these branches of government. Within these relative limits, however, the functions of each are fairly clearly defined. In the case of the President, responsibility consists primarily of the formulation of policies for consideration of the Congress and the manipulation of political means for achieving their enactment into law. In this respect, the President, acting as the agent of reformist groups less effectively represented in the Congress, has achieved significant innovations in regulatory policy. His role in the development of administrative programs, however, is much less extensive, the independence of regulatory agencies and their use of a judicial, case-by-case approach for policy formation being the most apparent reasons.

Congress, through enactment of regulatory statutes, control of programs through appropriations, and surveillance of administration, exercises its share of responsibility for the regulatory process. The quality of its performance in these respects varies greatly, however, particularly because the dispersed nature of its leadership and political composition makes difficult the achievement of sustained and consistent attention to regulatory programs. The independent commissions, considered by legislators as "arms of the Congress," contribute materially to Congress' ability to involve itself in the minutia of administrative regulation, but also demonstrate its corresponding inability to provide the type of leadership that administration of complex programs requires.

There has been a noticeable failure of efforts to integrate the regulatory commissions into executive departments under control of the President. Such efforts, in addition to clarifying important issues concerning the unity of the regulatory process and of administrative fairness, reveal the underlying political relationships of participants in the regulatory process. Failure of executive integration, therefore, demonstrates the relative weakness of groups supporting greater authority in the President, as compared with opposing groups and interests with better political access to the Congress.

Because joint presidential-congressional responsibility for the regulatory process is a fact of American governmental life, it does not follow that the results for effective policy development are in all respects satisfactory. It does mean, however, that 
attempts to remedy whatever inadequacies may be present will have to proceed, for the most part, in recognition of that fact of shared responsibility. The problem of achieving greater consistency and vigor in the administration of certain regulatory policies, and in their relations to other areas of governmental policy, is a case in point. No amount of wishful thinking or special pleading can remove the necessity of government's providing a better coordinated, more vigorous approach toward the problems of transportation in this country. Other observers find compelling need for similar improvements in the areas of communications, trade practices, and power resources regulation. ${ }^{78}$ There are those, of course, who deny that such problems exist, or if acknowledging their existence, contend that Congress is capable of remedying them, by either improving the quality of its statutes or perfecting the character of its legislative surveillance, or both. ${ }^{\mathbf{7 9}}$ Conversely, others continue to find a solution in drastic proposals for executive integration, with consequent dismemberment of the independent agencies and distribution of their functions to executive departments and specialized administrative courts. ${ }^{80}$ Neither of these solutions, however, will do: the former, because it provides no basis for the kind of direction that complex administration requires; the latter, since, at this juncture of our government's development, it is politically incapable of fulfillment, and also because it fails to provide an acceptable adjustment between the conflicting needs of a unified approach to individual regulatory programs and of procedural fairness.

It is, therefore, understandable-and appropriate-that other recent proposals for remedying the problems of coordination and planning have revealed more cautious and eclectic-and consequently, more realistic-approaches. The Landis and Redford reports are of this type. ${ }^{81}$ For example, the Landis report, assuming the necessity and wisdom of retaining existing regulatory agencies, proposed the creation within the Executive Office of the President of special offices for the coordination and development of policies in the areas of transportation, energy, and communications. These offices ". . . would need no regulatory powers,"82 but would serve as high-level staffs to the President for the study and development of policy recommendations in their respective fields, and as representatives of the President in contacts with the regulatory agencies and executive departments for the purpose of promoting cooperation and coordination in policy formation. Although there may be reason for questioning the ability of such offices to function as effectively as anticipated, particularly in view of their divorcement from administrative operations where the materials and staffs for adequate planning are found,

${ }^{78}$ Landis Report 24, 74; Eamette S. Redford, The President and the Regulatory Comamssions I, 6-8 (1960) (prepared by Professor Redford in his capacity of consultant to the President's Advisory Committee on Government Organization) [elsewhere cited as REDFond REPoRT].

${ }^{75}$ An early expression of this view is found in studies and reports prepared by The Brookings Institution in the late I930's. See, BLACHLY \& OATMAN, op. cit. supra note 33, at 168-82. A more recent example appears in the $\mathrm{CAB}$ memorandum on the Hector proposals, supra note 57 , at 29-34.

${ }^{80}$ Hector, supra note 38 , at $960-64$.

${ }^{81} \mathrm{Op}$. cit. supra notes 17,78 .

${ }^{82}$ LANDIS REPORT 77. 
the frankly empirical nature of the proposal has much to commend it. ${ }^{83}$ Not only does it provide a more formal (although, perhaps, inadequate) means for presidential recognition of, and attention to, the needs of regulatory policy development, but, by minimizing opposition of Congress, and clientele groups through avoidance of drastic reorganization plans, it accomplishes that goal in the only manner that our political system currently allows. As a result, with adequate personal support of the President, the arrangement may enable immediate attention to be given to significant problems of regulatory policy formation, while, at the same time, experience is gained and a basis is developed for possibly more permanent and adequate organizational methods.

Similarly, the report of Professor Redford avoids the extreme reorganization proposals traditionally associated with executive integration and acknowledges the need of accommodating the requirements of better overhead policy direction in the President to existing operations in regulatory commissions. ${ }^{84}$ In that way, it, too, seeks solutions to a serious issue now confronting the regulatory process, but in a manner that provides some possibility of success.

${ }^{88} I d$. at $76-77$.

84 Note, for example, the following quotation from this report: "Some authorities have suggested that executive responsibility can only be safeguarded if the executive and policy-making functions of commissions are transferred to executive departments and their quasi-judicial functions placed in completely independent agencies. This solution is drastic and is based on the doubtful assumption that the regulatory scrambled egg can be cleanly separated into an executive-policy determining yellow and a quasi-judicial white. The same objective may be attained through providing the President with means through which he can give policy guidance to the commissions for their day-to-day activities." Reprond REPORT 2. The necessary "means" of presidential leadership are set forth in $i d$. at 3-5. 